\title{
ANTYCZNE KAMIENIOŁOMY PROCONNESOS. ZARYS PROBLEMATYKI
}

\author{
THE ANCIENT PROCONNESOS QUARRIES. AN OUTLINE
}

\author{
Katarzyna Grala \\ Instytut Prahistorii, Uniwersytet im. Adama Mickiewicza \\ ul. Św. Marcin 78, 61-809 Poznań, Poland \\ Janusz Skoczylas \\ Instytut Geologii, Uniwersytet im. Adama Mickiewicza \\ ul. Maków Polnych 16,61-606 Poznań, Poland
}

\begin{abstract}
Authors of this article visited the Marmara island in August 2000 during a short research stay. It was aimed at recognition of at the current condition of the quarries and their ancient remains, preparation of photo and graphic documentation as well as collection of samples for petrographic, chemical, X-rays, and isotopic analyses. The quarries have been functioning since the ancient times until the present day. A marble called the "Marmara-White" is extracted from them. During construction of two new breakwaters in Saraylar, next to which the quarries are located, a Roman and early Byzantine cemetery was found that led to the archaeological studies of the island and consequently to the renewed interest in marble distribution in ancient times.
\end{abstract}

\section{WSTĘP}

W światowej literaturze, w tym archeologicznej, funkcjonuje wiele nazw marmurów, które w świetle mniej lub bardziej wiarygodnych ustaleń były wydobywane, wykorzystywane i przemieszczane od starożytności po dzień dzisiejszy. Jednym z tych marmurów jest surowiec o nazwie „Proconnesos”. Jednak o ile o innych marmurach mamy wiele informacji o miejscach ich wydobywania, o tyle o tym marmurze do niedawna wiadomo było stosunkowo najmniej. Także w samej Turcji, na terenie której znajdują się współczesne kamieniołomy tego marmuru, pojęcie marmuru „Proconnesos” do $197 \mathrm{l}$ r. nie funkcjonowało. Zresztą do dzisiaj handlowa nazwa tego eksportowanego marmuru brzmi „Marmara White”. 
Czasami potrzebne jest szczęście i w nowoczesnej archeologii, dysponującej doskonałym sprzętem i coraz bogatszą wiedzą o dawnych kulturach. Szczęśliwy traf podczas prac budowlanych przeprowadzanych w małej miejscowości Saraylar na wyspie Marmara doprowadził do odkrycia w 1971 r. nekropolii rzymskiej z marmurowymi sarkofagami.

Było wiadomo, że już od VIII w. p.n.e. na wyspie funkcjonowały kamieniołomy, w których wydobywano marmur, jednak wszystkje informacje ich dotyczące pochodziły $\mathrm{z}$ inskrypcji i archeologicznych odkryć spoza wyspy. Dopiero budowa dwóch falochronów pozwoliła na odsłonięcie ogromnej warstwy gruzu, którą były przykryte zabytki.

To odkrycie spowodowało, że wzrosło zainteresowanie nie tylko kamieniołomami znajdującymi się na wyspie, ale także zaczęto się zastanawiać nad ich powiązaniami z miejscami, w których ujawniono pozostałości warsztatów kamieniarskich na terenie północnej Turcji. Rezultatem tego zainteresowania było powstanie Departamentu Antycznego Ankara oraz rozpoczęcie badań prowadzonych przez N. Firathli, a kontynuowanych obecnie przez N. Asgari. Na arenie międzynarodowej rozgorzała dyskusja na temat technik wydobywczych oraz dystrybucji marmurów $z$ innych kamieniołomów antycznych. Ukazało się wiele publikacji dotyczących tej tematyki, między innymi: W. Deichmanna ${ }^{1}$, J.B. Ward-Perkinsa ${ }^{2}$, W.F. Betscha ${ }^{3}$, P. Pensabene ${ }^{4}$, J.P. Sodini ${ }^{5}$, C. Barsanti ${ }^{6}$ i wiele innych.

W sierpniu 2000 r. odbyliśmy krótką podróż na wyspę Marmara, aby sprawdzić obecny stan kamieniołomów i pozostałości antycznych zabytków oraz wykonać dokumentację fotograficzną i rysunkową i pobrać próbki marmurów w celu wykonania analiz petrograficznych, chemicznych, rentgenowskich oraz izotopowych. Ich wyniki powinny stanowić bazę porównawczą dla interpretacji marmurów „Proconnesos" z różnych obiektów archeologicznych ${ }^{7}$.

\section{POŁOŻENIE OBSZARU BADAŃ}

Wyspa Marmara (antyczne Proconnesos) jest największą z grupy wysp znajdujących się na morzu Marmara. Obecnie jej nazwa brzmi Marmara Adasi; wchodzi w skład terytorium Turcji. Jej górzysta powierzchnia zajmuje obszar $75 \mathrm{~km}^{2}$. Dłu-

${ }^{1}$ Deichmann 1969, s. 291-307.

${ }^{2}$ Ward-Perkins 1972, s. 138-158.

${ }^{3}$ Betsch 1977, s. 287-289.

${ }^{4}$ Mona, Pensabene 1977, s. 147-173.

${ }^{5}$ Sodini 1977, s. 423-450.

${ }^{6}$ Barsanti 1989, s. 91-221.

${ }^{7}$ Badania prowadzono $w$ ramach programów badawczych Ekspedycji Archeologicznej UAM Novae - Mezja Inferior i Chersonesu Taurydzkiego - Krym, Ukraina, finansowanych przez KBN i UAM Poznań. 
gość wyspy wynosi $18 \mathrm{~km}$ ze wschodu na zachód, a szerokość $10 \mathrm{~km} \mathrm{z}$ północy na południe. Najwyższy szczyt osiąga 699 m n.p.m. Z kolei śródlądowe morze Marmara, oblewające północno-zachodnie wybrzeża Azji Mniejszej oraz Półwysep Bałkański, wchodzi w skład łańcucha połączonych ze sobą mórz (Czarnego, Marmara, Śródziemnego), które oddzielają Europę od Azji i Afryki. Nazwa morza, a także wyspy, pochodzi od greckiego „marmaros”, czyli marmuru. Grecy nazywali to morze „Propontis”, czyli przedsionek Pontu - Morza Czarnego. Morze Marmara ma kształt zbliżony do elipsy. Jego długość przekracza $200 \mathrm{~km}$, średnia głębokość wynosi $250 \mathrm{~m}$, a maksymalna $1389 \mathrm{~m}$. Powierzchnię morza ocenia się na $1200 \mathrm{~km}^{2}$, objętość zaś na $30000 \mathrm{~km}^{3}$. Zasolenie morza jest duże i wynosi $26 \%$ w warstwie powierzchniowej, do $38 \%$ w warstwie dennej ${ }^{8}$.

Morze Marmara wypełnia tektoniczne zapadlisko powstałe na przełomie trzecioi czwartorzędu. Północno-zachodnia część Anatolii, przylegająca do morza Marmara, łączyła się jeszcze u schyłku trzeciorzędu z górami tracko-rodopskimi. Dopiero spękania skorupy ziemskiej doprowadziły do powstania zapadliska tektonicznego, a dawne łożysko rzeczne Dardaneli i Bosforu zamieniły w cieśniny. Obie jednak cieśniny bardzo różnią się od siebie. Dardanele łącząc morze Marmara z Morzem Egej-

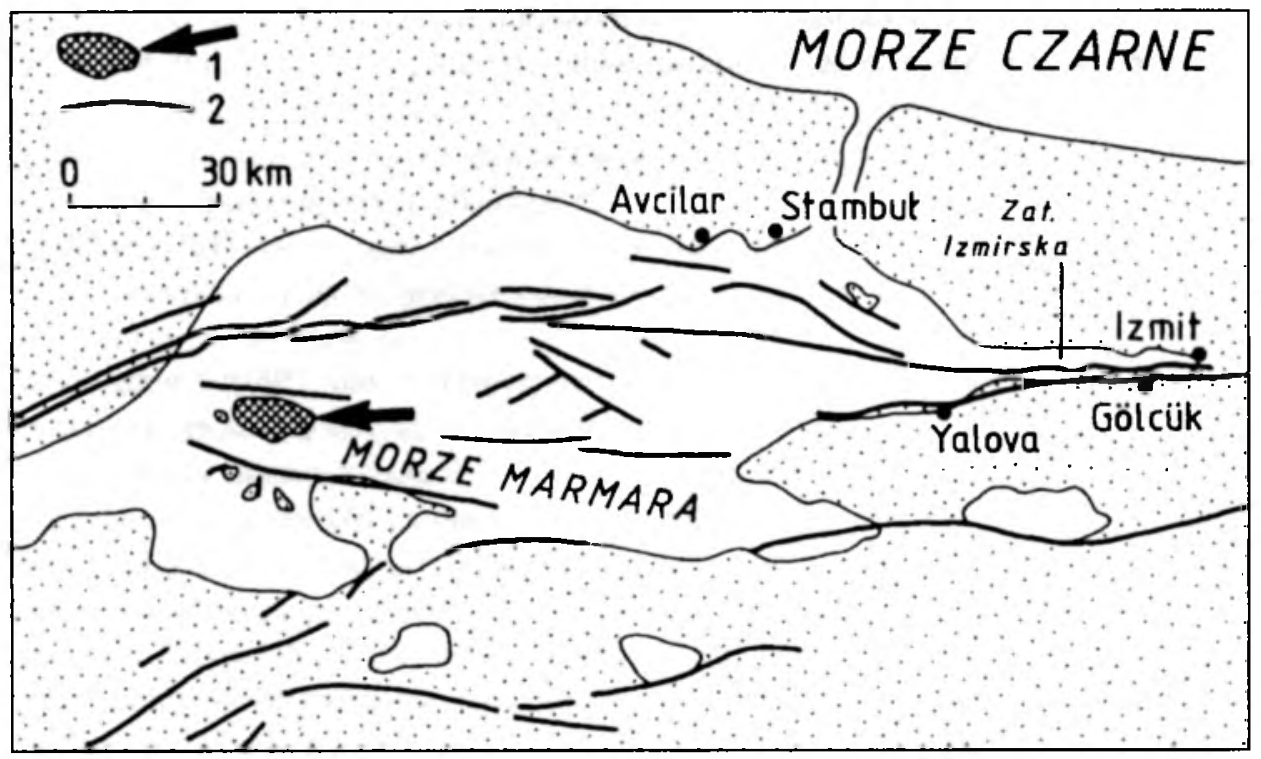

Ryc. 1. Położenie geograficzne i tektoniczne wyspy Marmara.

1 - wyspa Marmara i starożytne Proconnesos, 2 - linie uskoków

Fig. 1. Geographical and tectonic position of the Marmara Island.

1 - the Marmara island and ancient Proconnesos, 2 - lines of faults

${ }^{8}$ Encyklopedia 1997, s. 11-53, 491-500. 
skim są cieśniną długa, mają około $120 \mathrm{~km}$ długości oraz 1,3-27 km szerokości. Cieśnina ta jest stosunkowo płytka, jej maksymalna głębokość wynosi $153 \mathrm{~m}$, a minimalna $29 \mathrm{~m}$. Przecina ona płytę trzeciorzędowych wapieni, margli i piaskowców. Jej brzegi są płaskie i bezleśne. Cieśnina Bosfor natomiast wije się korytem, którego długość wynosi około $31 \mathrm{~km}$, a szerokość $0,7-3,8 \mathrm{~km}$. Brzegi jej są wysokie, silnie rozczłonkowane (ryc. 1). Przecina ona stare paleozoiczne formacje łupków i piaskowców, a także stare skały wulkaniczne. Obie cieśniny są drogami wymiany wód, przy czym dużo większy jest odpływ wód Morza Czarnego niż odpływ Morza Egejskiego.

Basen morza Marmara jest rejonem częstych trzęsień ziemi. Szczególnie straszliwe w skutkach było trzęsienie z 17 lipca 1999 r. w rejonie Izmitu (antyczna Nicomedia), które pochłonęło wiele ofiar i wyrządziło trudne do wyobrażenia i oszacowania straty. Trzęsienie miało miejsce $15 \mathrm{~km}$ pod ziemią, na wschód od Gölcük, wzdłuż Uskoku Północnoanatolijskiego (ryc. 1). Uskok ten ciagnie się przez $1600 \mathrm{~km}$, od wschodniej Turcji, po Grecję i jest w zasadzie siecią mniejszych uskoków, które dzielą dwie płyty litosfery: euroazjatycką i dużo mniejszą anatolijską ${ }^{9}$. Wprawdzie płyty te są ze sobą połączone, sczepione, jednak płyta anatolijska przesuwa się szybciej na zachód, w stronę Grecji z szybkością $2,5 \mathrm{~m}$ na 100 lat $^{10}$. Uskok Północnoanatolijski od 1939 r. wywołał 13 dużych trzęsień ziemi. Obecnie największy niepokój wzbudza odcinek uskoku o długości około $160 \mathrm{~km}$ pod dnem morza Marmara, przechodzący około $25 \mathrm{~km}$ od Stambułu (ryc. 1). W ciagu minionych 2000 lat tereny te niszczyło ponad 600 udokumentowanych trzęsień ziemi, w tym 40 o sile ponad 7 stopni w skali Richtera. Fala potężnych wstrząsów miała miejsce od połowy IV w. do połowy VI w. i dotknęła wszystkie większe miasta tego rejonu. Ta zagadkowa seria trzęsień ziemi zyskała określenie wczesnobizantyjskiego paroksyzmu tektonicznego ${ }^{11}$.

Uskok ten mógł wywołać także straszliwą powódź około 7500 lat temu, która zalała basen Morza Czarnego. Istnieje przypuszczenie, że pod koniec epoki lodowcowej globalny poziom wód morskich podniósł się. Jednak naturalna zapora w postaci dzisiejszego Bosforu powstrzymywała wody morza Marmara. Gdy wreszcie tama ta się zawaliła, około $40 \mathrm{~km}^{3}$ wody morskiej dziennie przelewało się do Morza Czarnego, leżącego około $150 \mathrm{~m}$ niżej. Wody morza mogły się posuwać z prędkością $1,5 \mathrm{~km}$ dziennie, i to w ciagu wielu miesięcy. Ta teoria W. Rijana i W. Pitmana zyskała nowe wsparcie w postaci odkrycia dokonanego przez R. Ballarda, który odnalazł $150 \mathrm{~m}$ pod wodą ,plażę" zawierającą muszle słodkowodnych małży, datowanych na około 7800 lat oraz młodsze (7300 lat) muszle małży słonowodnych ${ }^{12}$.

\footnotetext{
${ }^{9}$ Miłar 1987, s. 515-555; Zuchiewicz 2000, s. 971-990.

${ }^{10}$ Gore 2000, s. 32-71; Tectonics 1982, s. 515-555.

${ }^{11}$ Gore 2000, s. 32-71; Herz 1988, s. 6-10; Piccardi 2000, s. 219-251.

${ }^{12}$ Gore 2000, s. 32-71.
} 


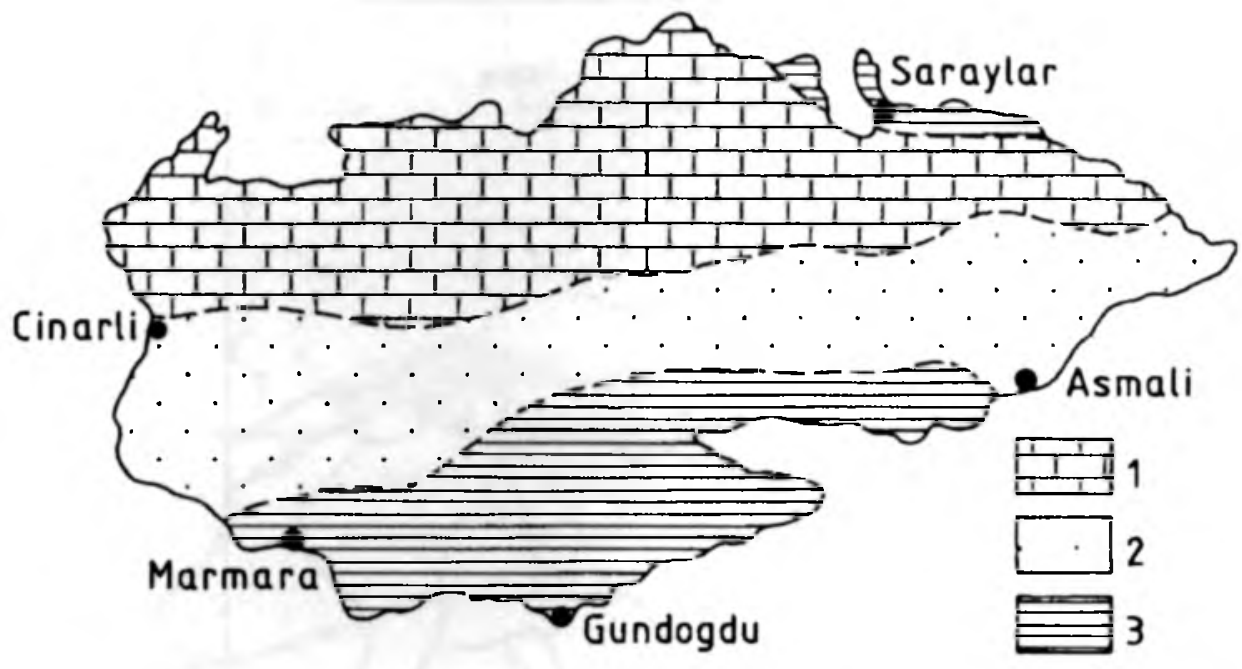

Ryc. 2. Budowa geologiczna wyspy Marmara (wg Mona, Pensabene 1977).

l-marmury, 2-gnejsy, 3 - lupki

Fig. 2. Geology of the Marmara Island (after Mona, Pensabene 1977).

1 - marble. 2 - gneiss, 3 - schist

Na wyspie Marmara od czasów antycznych po dzień dzisiejszy funkcjonują kamieniołomy i warsztaty kamieniarskie.

Warsztaty kamieniarskie znajdują się w Saraylar, miejscowości wokół której usytuowane są kamieniołomy. Schematyczny rys budowy geologicznej tej wyspy przedstawia ryc. 2. Marmury budują jej część północną część środkową tworzą gnejsy, na południu zaś występują łupki muskowitowe. Bardzo interesujące są strefy kontaktowe tych trzech rodzajów skał. Współcześnie leżąca w północnej części osada Saraylar jest ośrodkiem intensywnej eksploatacji marmurów (fot. 1, 2). Eksploatacja odbywa się dziś nieustannie, przez 24 godziny na dobę. Zatem najbliższe okolice tej osady przedstawiają krajobraz „księżycowy”, gdzie obok śnieżnobiałych ścian marmurów zalegają hałdy odpadów eksploatacyjnych i produkcyjnych. To intensywne wydobycie zatarło prawdopodobnie wszelkie ewentualne ślady wcześniejszej eksploatacji, obecnie znajdywane elementy starożytnego kamieniarstwa są skrupulatnie przechowywane $w$ zorganizowanych naprędce siedmiu lapidariach (ryc. 3).

Współcześnie eksploatacja polega na mechanicznym wierceniu otworów i odspajaniu dużych brył marmurów, które następnie - jeszcze w kamieniołomach cięte są na bloki o wymiarach $120 \times 100 \times 80 \mathrm{~cm}$ oraz $240 \times 180 \times 120 \mathrm{~cm}$. Takie bloki wywożone są przez buldożery na skraj kamieniołomów i ładowane na ciężarówki, które z kolei zawożą marmury do portu, gdzie przeładowywane są na statki. 


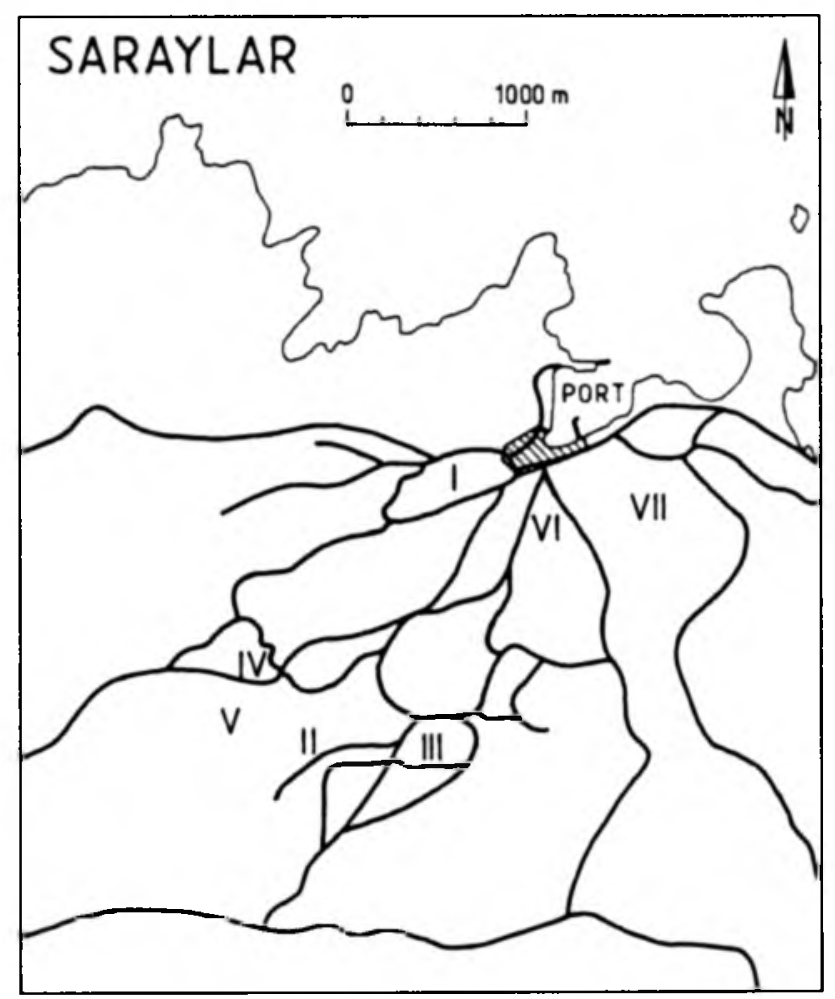

Ryc. 3. Usytuowanie lapidariów w okolicy Saraylar (wg Asgari 1978)

Fig. 3. Location of collections of stones around Saraylar (after Asgari 1978)

Marmury wykazują barwę biała, miejscami szara, lecz przecinane są ciemnymi „warstewkami” (paskami). W badaniach mikroskopowych wyróżnia się dwa rodzaje marmurów: średnioziarniste marmury kalcytowe oraz drobnoziarniste marmury kalcytowo-dolomityczne $\mathrm{z}$ muskowitem. Ciemne paski tworzą minerały mikroskopowo nieprzeźroczyste. Marmury cechuje zdolność do polerowania, szlifowania, wygładzania.

\section{HISTORIA BADAŃ}

W 1971 r. w zachodniej części Saraylar rozpoczęto budowę dwóch falochronów, wynikiem czego było odkrycie nekropolii znajdującej się w jednej z dolin i rozpoczęcie badań archeologicznych na terenie kamieniołomów. Nekropolia ta leży między wioską a doliną i rozciąga się w kierunku wschód - zachód (ryc. 4). Podczas tych badań nie odkryto żadnych zabytków z okresu greckiego, zarejestrowano nato- 


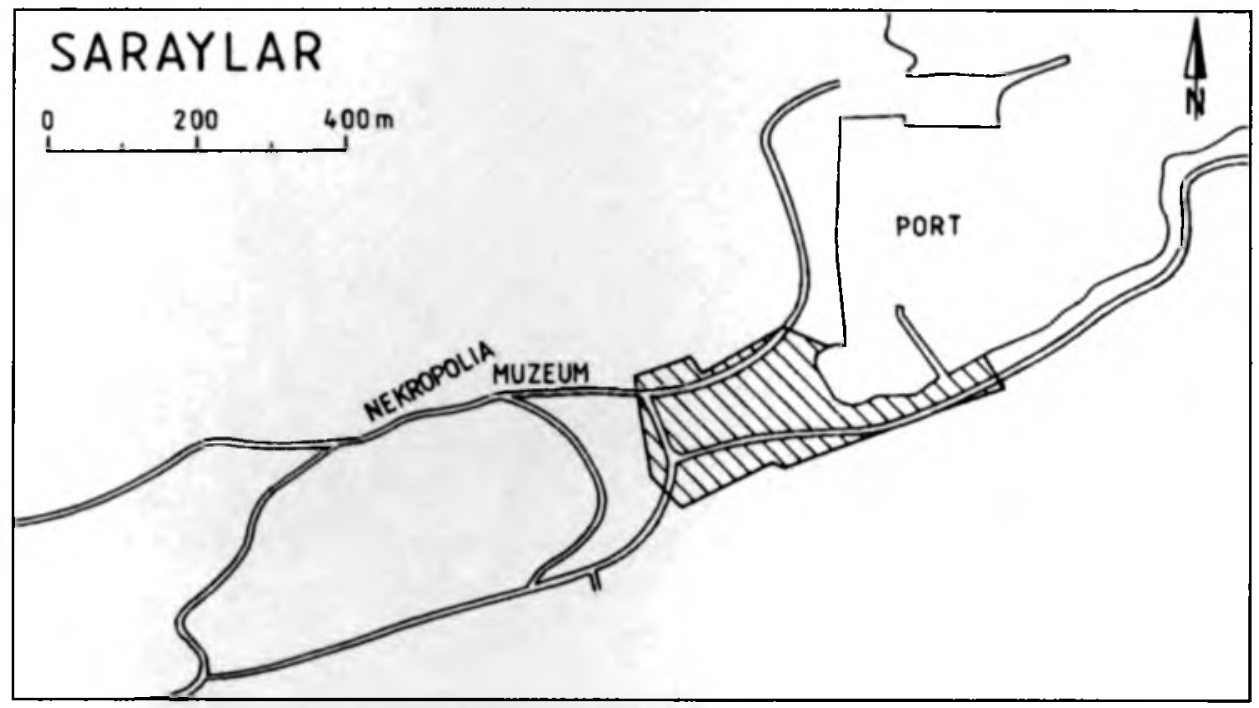

Ryc. 4. Położenie portu i pierwszej odkrytej nekropolii na wyspie Marmara (wg Asgari 1978)

Fig. 4. Location of harbor and the first discovered cemetery on the Marmara Island (after Asgari 1978)

miast liczne obiekty $z$ okresu rzymskiego i bizantyjskiego ${ }^{13}$. Na terenie nekropolii odsłonięto około 48 sarkofagów, z czego 10 in situ. Były to grobowce rodzinne biednych ludzi - zawierały po kilka szkieletów każdy. Wszystkie sarkofagi miały wady produkcyjne, które powodowały, że nie nadawały się do eksportu. Rozszerzając badania wyodrębniono siedem antycznych stanowisk, w których wykonywano wstępną obróbkę wyrobów marmurowych. Podczas naszego pobytu udało się odwiedzić cztery z nich. Część wyrobów marmurowych znajduje się dziś w lapidarium przy nekropolii, w którym umieszczono 84 zabytki w postaci kolumn, kapiteli, sarkofagów i rzeźby w różnych stadiach obróbki (fot. 3,4).

Niezbyt wiele wiadomo o historii zasiedlenia wyspy. Ze źródeł pisanych dowiadujemy się, że wyspa została skolonizowana przez mieszkańców Miletu w połowie VIII w. p.n.e., a następnie podobna kolonizacja miała miejsce z Cyzico, które było wówczas największym miastem w pobliżu ${ }^{14}$. Kamieniołomy były sławne już w IV w. p.n.e., ponieważ znamy je z przekazów Witruwiusza, opisującego wykorzystanie marmuru „Proconnesos” do budowy mauzoleum w Halikarnasie (,pałac potężnego króla Mauzolosa w Halikarnasie, chociaż całą ornamentykę ma $\mathrm{z}$ marmuru proconnesos, ściany ma z cegły..." - II, 8,10$)^{15}$.

Prace nad marmurem i jego eksport musiały być praktykowane na wyspie od dawna, ale dopiero w I w. n.e. zaczęło się wydobycie na dużą skalę, kiedy za pano-

\footnotetext{
${ }^{13}$ Asgari 1978, s. 467, 468.

${ }^{14}$ Hasluk 1910 , s. $30-35$.

${ }^{15}$ Witruwiusz 1999, s. 61.
} 


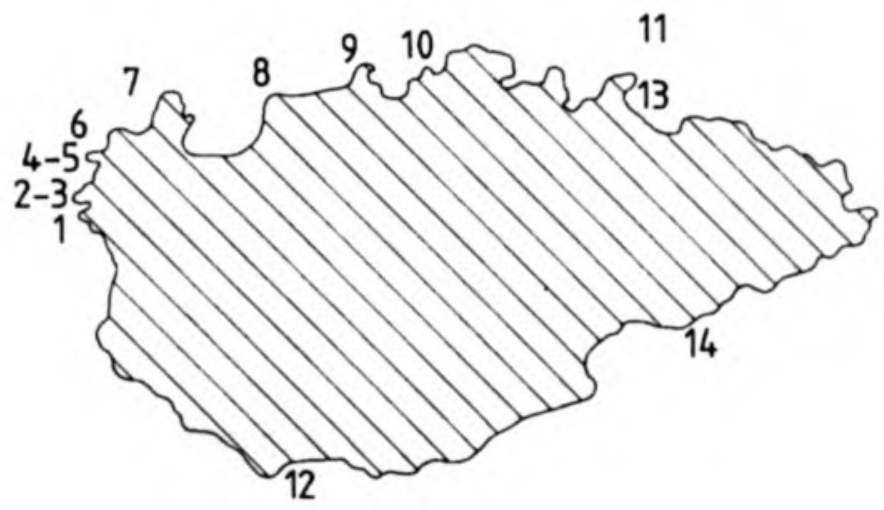

Ryc. 5. Rozmieszczenie podwodnych znalezisk archeologicznych, zatopionych w trakcie transportu

Fig. 5. Distribution of underwater archaeological finds sunk during transport

wania Tyberiusza kamieniołomy zostały zreorganizowane i przeszły na własność państwowa ${ }^{16}$. W rezultacie wyspa stała się wielkim centrum produkcyjnym i w ciagu II i III stulecia wyroby z niej pochodzące zaczęły dominować na rynkach wschodniej części Morza Śródziemnego, jak również marmur „Poconnesos” zaczął stanowić nad Morzem Czarnym dużą konkurencję dla marmuru pentelickiego z Attyki (ryc. 6).

W ciągu kilkudziesięciu lat rozwinęła się baza zupełnie nowego systemu produkcji i zaopatrzenia, który rozwijany i doskonalony miał przetrwać z niewielkimi zmianami aż do późnego antyku. Produkcja wyrobów $z$ marmuru odbywała się albo na wyspie, albo w ośrodkach nadmorskich w Cyzico i Nicomedii, gdzie znajdowały się warsztaty i magazyny. Nicomedia była wówczas administracyjną stolica Bitynii. Doskonałym źródłem jest list Pliniusza do Trajana, w którym nadawca zaleca wykopanie kanału łączącego Nicomedię z pobliskim jeziorem Sophon, w związku $\mathrm{z}$ trudnościami, jakie sprawia transport lądowy marmuru pochodzącego nie tylko $z$ Proconnesos ${ }^{17}$.

W IV w. produkcja odbywała się w głównej mierze w warsztatach Konstantynopola, które identyfikowały się już z nową stolicą administracyjną. Eksport był najbardziej rozwinięty od drugiej połowy V do pierwszej połowy VI w.

Fakt, że kamieniołomy na Proconnesos mogły eksportować duże ilości wyrobów na rynki zagraniczne, był rezultatem położenia złóż marmuru w bezpośredniej bliskości morza. Niższa cena marmuru wynikała także między innymi z tańszego morskiego transportu.

Pod koniec VI w. na dużą skalę praktykowano wtórne używanie wcześniej wykonanych elementów architektonicznych, co w rezultacie zmniejszyło eksploatację marmuru, a także - ze względu na częste ataki ze strony Persów i Arabów - obniży-

\footnotetext{
${ }^{16}$ Wiegartz 1974, s. 346.

${ }^{17}$ Plinius Gaius Caesilius (Minor) $1982(X, 42)$.
} 


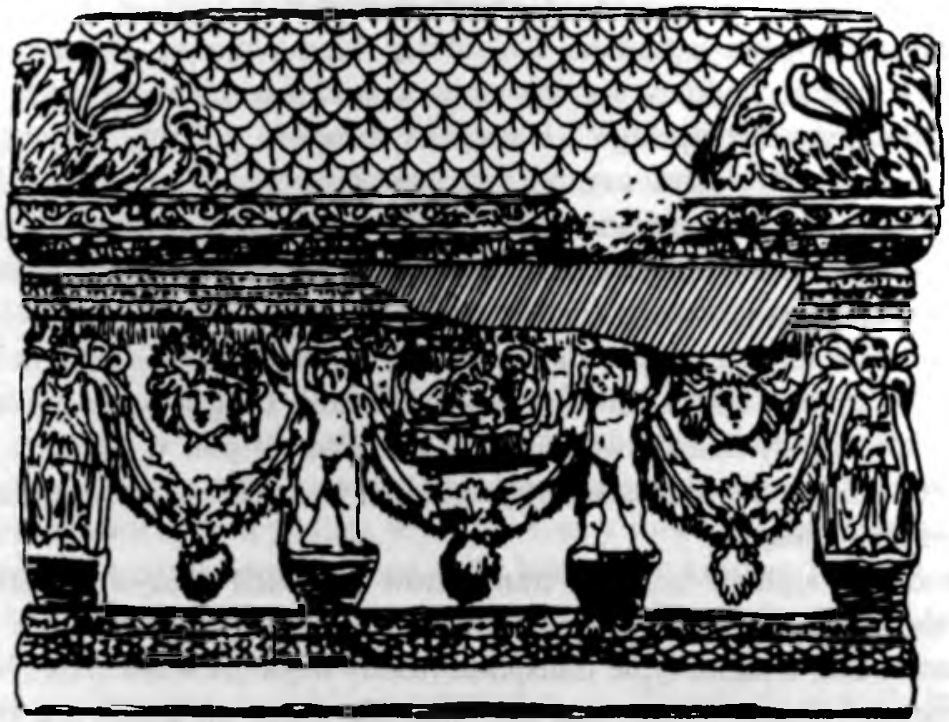

Ryc. 6. Przykład najczęściej eksportowanego sarkofagu „girlandowego” wykonywanego z marmuru „Proconnesos"

Fig. 6. An example of the most commonly exported "garland" sarcophagus made of the "Proconnesos" marble

żyło cenę i poziom produkcji ${ }^{18}$. Począwszy od VIII w. wyspa została przeobrażona w miejsce dla zesłańców religijnych i politycznych, usuniętych z Konstantynopola ${ }^{19}$.

Ponowny renesans kamieniołomy przeżywają w IX w., kiedy wznowiono działalność wydobywczą i produkcyjną na skalę podobną jak w V i VI w. ${ }^{20}$ Działalność tę poświadczają wyroby eksportowane do Bułgarii i Rusi od X do XIII w., a także powszechne stosowanie marmuru „Proconnesos” w pałacach Konstantynopola aż do XIV w. ${ }^{21} \mathrm{Z}$ archiwów otomańskich dowiadujemy się, że kamieniołomy dość systematycznie zaopatrywały późniejsze warsztaty w Stambule od XVI do XIX w.

Większość ludności na wyspie stanowili Grecy, którzy pracowali w kamieniołomach. W 1923 r. Turcja stała się republiką. Grecy byli zmuszeni opuścić wyspę,

\footnotetext{
${ }^{18}$ Herman, Sodini 1977, s. 501.

${ }^{19}$ Hasluck 1909, s. 10.

${ }^{20}$ Betsch 1977, s. 287-289.

${ }^{21}$ Caneva-Dečevska 1984.
} 
a do warsztatów przybyła ludność turecka z Ayancik nad Morzem Czarnym. Dziś większość mieszkańców Saraylar składa się z ludzi z Ayancik ${ }^{22}$.

Źródła pisane dotyczące wyspy Marmara to przede wszystkim relacje podróżników, z których można wymienić Cristoforo Buondelmonti, Reverendo Covela i Texiera. Dzienniki podróży są ilustrowane wieloma interesującymi rycinami. W „Liber Insularum Archipelagii”, historycznym opisie podróży na wyspy Morza Egejskiego i morza Marmara, zawarta jest najstarsza prezentacja wyspy Proconnesos, opracowana w Rodi pomiędzy rokiem 1420 a 1430 przez florenckiego amatora przygód Cristoforo Buondelmonti (kodeks Rossiano 702 Biblioteki Watykańskiej) ${ }^{23}$.

Ważnym źródłem jest mapa narysowana przez Reverendo Covela w 1677 r., na której przedstawione są zarysy wybrzeży z przylądkiem Cyzico i małym archipelagiem wysp Marmara: Pasha, Limani, Aphia, Koutali i największą Proconnesos ${ }^{24}$. Texier w 1848 r. przy okazji swej podróży naszkicował port w Saraylar, ukazując zupełnie dziś zniszczoną basztę bizantyjską, która wznosiła się na szczycie wzgórza i broniła do niego dostępu ${ }^{25}$.

Pomimo niewątpliwie licznych transportów morskich różnych marmurów, zachowało się bardzo mało odnośnych świadectw. Są dwa źródła, które zawieraja wyraźne wzmianki o takim typie transportu (teksty hagiograficzne o dużym znaczeniu dokumentacyjnym). Wydarzenia opowiedziane przez anonimowych kronikarzy, chociaż mają ton nieco anegdotyczny i legendarny, $\mathrm{z}$ dużym prawdopodobieństwem odzwiercjedlają ówczesne sytuacje i fakty.

Pierwszy tekst powstał w pierwszej połowie VII w. i stanowi część opowiadania pt. „Cuda Św. Jerzego”, drugi jest jednym z opowiadań „O cudach Św. Demetria” i powstał w drugiej połowie VII w. Według pierwszego tekstu cesarz (nie określono, który) postanowił odbudować w swej rodzinnej krainie Lidia Diospolis w Palestynie kościół, w którym znajdowały się relikwie św. Jerzego. Po rozpoczęciu budowy zdano sobie sprawę, że teren, na którym budowano, nie oferował odpowiednich materiałów do wykonania kościelnych kolumn. Sprowadzono więc gotowe kolumny $\mathrm{z}$ dalekiego kraju, gdzie był odpowiedni surowiec. Transportowano je do Palestyny na specjalnie w tym celu skonstruowanych barkach ${ }^{26}$.

Bardziej znany jest drugi tekst zawierający opis cudownych interwencji św. Demetria na rzecz Cypriana, biskupa Thenai. Został w nim przypomniany powrót pewnego statku ze stolicy do miasta Bizaceny, $\mathrm{z}$ ładunkiem marmuru zawierającym serię kolumn, ambonę i cyborium, który niespodziewanie został użyty w kościele budowanym przez biskupa Cypriana na cześć św. Demetria ${ }^{27}$.

\footnotetext{
${ }^{22}$ Asgari 1978, s. 469.

${ }^{23}$ Weiss 1964, s. $105-116$.

${ }^{24}$ Hasluck 1906, s. 211, 212.

${ }^{25}$ Texier 1862, s. 161.

${ }^{26}$ Aufhauser 1913, s. 2-8.

${ }^{27}$ Lemerle 1979, s. 234-236.
} 
Jednymi z ważniejszych kategorii antycznych źródeł pisanych są inskrypcje nagrobkowe i dziękczynne, osób prywatnych, weteranów legionowych, jak również kamieniarzy z Nicomedii. Zostaly one wykonane w marmurze „Proconnesos”. Przykłady to: datowana na połowę II w. inskrypcja pochodząca z północno-wschodniej Bułgarii z Nicopolis ad Istrum, zawierająca dedykację dla Heraklesa od dwóch kamieniarzy $z$ Nicomedii o imionach Maximus i Neikon ${ }^{28}$, epitafium dla Aureliusa Andronikusa i jego żony Aebuti Fortuny, który sprowadzał marmur „Proconnesos” z Nicomedii, pochodzące $z$ III $w$. $z$ okolic Intermana Nahars $w$ Umbrii ${ }^{29}$ oraz dedykacja ufundowana przez mieszkańców Olbii znajdująca się na budynku laźni, wystawiona podczas rządów Septimiusa Severusa i Caracallii, kończąca się imionami architektów, obywateli Nicomedii i Tomis ${ }^{30}$.

Najliczniejszą kategorią źródel dotyczących tego tematu są zabytki archeologiczne - głównie w postaci sarkofagów, elementów architektonicznych i rzeźby. Jako przykład mogą posłużyć rzeźby znajdujące się w bazylice św. Pawła w Rzymie, której budowa została podjęta w ciągu IV w. z funduszy państwowych ${ }^{31}$. Ważne są zabytki z sanktuarium S. Mena nella Mareotide; którego budowa rozpoczęta była przez cesarza Arkadiusza, kontynuowana przez Teodozjusza II, a zakończona podczas rządów cesarza Zenona $(474-491)^{32}$.

Marmury $z$ konstantynopolskich warsztatów znajdowały się $w$ wielu budowlach, np. w sanktuarium wzniesionym na cześć św. Tekli w Meriamlik obok Seleuciadi w Cilici ${ }^{33}$, w sanktuarium ofiarowanym Theotokosowi na górze Garizim w Sama$\mathrm{rii}^{34}$, w kościele i klasztorze wzniesionym na cześć apostoła Barnaby w Salamis na Cyprze $^{35}$, w klasztorze Abu Makar na pustyni Nitria ${ }^{36}$, czy w bazylice biskupiej z Novae w Bulgarii ${ }^{37}$.

\section{TECHNIKI EKSPLOATACJI}

Dziś podstawę badań nad chronologią kamieniołomów stanowią głównie dzieje użytkowania kamienia, w tych przypadkach oczywiście, gdy ustalono pochodzenie surowca, z którego wykonano datowany zabytek. Miejsca, z których pobierano materiał przez dłuższy okres, całymi wiekami, nie są w równym stopniu przydatne do badań tego rodzaju jak kamieniołomy, w których eksploracja była krótkotrwała.

\footnotetext{
${ }^{28}$ Ward-Perkins 1980, s. 34 (IG Bulg II: 674).

${ }^{29}$ Ward-Perkins 1980 , s. 34 (IG XIV: 2247).

${ }^{310}$ Latyschev 1965, s. 174.

${ }^{31}$ Krautheimer 1980, s. 123.

${ }^{32}$ Schläger 1963, s. 114-120.

${ }^{33}$ Herzfeld; Guyer 1930, s. 73, 74.

${ }^{34}$ Schneider 1951, s. 211-234.

${ }^{35}$ Megaw 1974, s. 57-88.

${ }^{36}$ White 1932, s. 224.

${ }^{37}$ Biernacki 1997, s. 71-80.
} 
Tam bowiem, gdzie wydobycie kontynuowano przez szereg stuleci, jak na przykład na Proconnesos, prace późniejsze zatarły - jeśli nie całkowicie, to przynajmniej w stopniu nie dającym się obecnie ustalić - wyrobiska wcześniejsze. Kamieniołomy w tym stanie, w jakim mamy możliwość badać je dziś, reprezentują końcowy etap swej eksploatacji, gdyż każda wydobyta warstwa skały niweczy ślady prac poprzednich.

Przenosząc na starożytność doświadczenia nowożytnych górników i kamieniarzy ustalono wykaz zagadnień dotyczących techniki górnictwa kamiennego ${ }^{38}$. Są to: wybór miejsca pod kamieniołom, sposób dotarcia do złoża produkcyjnego, roboty początkowe, rozwój pionowy i poziomy kamieniołomu, sposoby wyłamywania kamienia i używane do tego narzędzia, uwzględnienie i wykorzystanie do celów wydobywczych naturalnych właściwości skały (twardość, uwarstwienie i jego kierunek, jej spękanie, łupliwość i in.) oraz gospodarkę wodą.

We wczesnych okresach użytkowania kamieniołomów do eksploatacji surowca skalnego stosowano dłuta metalowe, głównie miedziane, później miedziane i wykonywane z brązu, a jeszcze później żelazne. Stosowano także drewniane i metalowe kliny oraz narzędzia typu zaostrzonego młota - oskarda ${ }^{39}$. Blok o regularnych, prostopadłościennych kształtach wydzielano $\mathrm{z}$ calizny przez wykonanie długim dłutem rowk6́w dookoła przyszłych bocznych ścianek bryły; następnie działano klinami, odrywając za ich pomoca blok od dołu ${ }^{40}$. Drewniane kliny polewano woda, co powodowało ich pęcznienie i powolne pękanie skały. Techniki wydobywcze zostały znacznie usprawnione przez wprowadzenie do produkcji narzędzi żelaza ${ }^{41}$.

Aby uzyskać trzon małej kolumny długości około $2 \mathrm{~m}$ wykuwano w skale, za pomocą długiego dłuta, rowek (o szerokości $15-20 \mathrm{~cm}$ ) wokół średnicy planowanego trzonu kolumny. Otrzymany w ten sposób trzon odrywano od skały lekko go podcinając w dolnej partii i wyłamując ${ }^{42}$.

W kamieniołomach okresu rzymskiego, eksploatowanych na szerszą skalę, produkowano ogromne, monolityczne kolumny. Pracę przy ich pozyskiwaniu zaczynano od wyznaczenia w skale długości kolumny przez wykonanie głębokich wcięć określających przyszłą podstawę i szczyt trzonu. Następnie między zaznaczonymi wcięciami wykuwano wypukła powierzchnię połowy walca, jakby przeciętego wzdłuż. Z kolei wzdłuż obu boków otrzymanej w ten sposób półkolumny ryto głęboką bruzdę lub kuto otwory, w które zakładano kliny. Powstałe na skutek nacisku klinów linie napięć prowadziły do wyłamania się drugiej połówki kolumny o równie wypukłej, jak pierwsza, powierzchni. Otrzymany w ten sposób monolit należało z kolei odpowiednio opracować i wygładzićc ${ }^{43}$ (ryc. 5).

\footnotetext{
${ }^{38}$ Czeżowski 1946, s. 103.

${ }^{39}$ Lucas 1948, s. 48.

${ }^{40}$ Roder 1971 s. $298,299$.

${ }^{41}$ Durkin, Lister 1983, s. 82

${ }^{42}$ Lepsius 1890, s. 27.

${ }^{43}$ Blümner 1884, s. 79.
} 


\section{UWAGI KOŃCOWE}

Nie ulega już wątpliwości, że badania archeologiczne przeprowadzone w Saraylar mają ogromne znaczenie dla nauki, a odkrycie kolejnych zabytków na terenie współczesnych kamieniołomów pozwoliło na uzyskanie wielu cennych informacji o antycznych sposobach wydobycia i obróbki marmuru. Takie odkrycia powinno się trwale zabezpieczać, jednak nie zawsze są na to fundusze. W Saraylar, w zachodniej jego części, stworzono lapidarium, w którym zgromadzono zabytki znalezione wokół miasteczka. Na terenie kamieniołomów, które funkcjonują do dziś, w specjalnych, odosobnionych miejscach zgromadzono zabytki znalezione podczas eksploatacji. Wszystkie są zinwentaryzowane, lecz nie mają żadnego trwałego zabezpieczenia, narażone są na działanie czynników atmosferycznych i uszkodzenia mechaniczne podczas ich przenoszenia i transportowania. Detale architektoniczne powinny być konserwowane natychmiast po odsłonięciu, w przeciwnym razie następują nieodwracalne straty; zabytki ulegają przesuszeniu lub zawilgoceniu, co umożliwia atak biologiczny. Także woda opadowa osiadająca na powierzchni i wnikająca w strukturę materiału kamiennego osadza skażenia w postaci gazów, aerozoli i cząstek stałych. Skutki braku prawidłowego zabezpieczenia są dziś bardzo widoczne, po prawie trzydziestu latach od założenia muzeum.

Wprawdzie główny cel ekspedycji, czyli znalezienie miejsc starożytnej eksploatacji marmurów, nie został osiągnięty, jednak poznanie $z$ autopsji marmurów in situ, w złożu, a także zbadanie wielu zachowanych starożytnych rzeźb i elementów architektonicznych wykonanych $z$ tego surowca, pozwoliło autorom docenić znaczenie i potencjalne możliwości tej wyspy jako potężnego źródła marmurowego materiału skalnego. Zasoby tego surowca ciagle są znaczne, stąd ich współczesna intensywna eksploatacja, która być może zatarła ewentualne ślady wcześniejszego wydobycia. Pobranie próbek marmurów ze złoża, a także z wykonanych na miejscu elementów architektonicznych i rzeźbiarskich, stanowi cenny materiał dla badań petrograficznych i fizyko-chemicznych. Jest także bezcennym materiałem porównawczym dla badań nad prowieniencją marmurów, tak przecież preferowanych w starożytnym świecie.

Marmury z Proconnesos nie mają nadzwyczajnych walorów fizycznych i estetycznych. Występujące ciemne warstewki minerałów nieprzezroczystych raczej obniżają wartość estetyczną tej skały. Co zatem mogło decydować o tak powszechnym i rozległym rozprzestrzenieniu rzeźb i elementów architektonicznych wykonywanych z tego marmuru? Wydaje się, że działały tutaj dwa czynniki, oba związane z położeniem wyspy oraz tutejszych złóż. Wyspa Marmara leżała na szlaku komunikacyjnym łączącym wybrzeża Morza Śródziemnego, a szczególnie Morza Egejskiego, z Nadczarnomorzem. Miała więc ogromne znaczenie polityczne, strategiczne i gospodarcze. $Z$ kolei występowanie marmurów na wybrzeżu ułatwiało transport, ograniczając do minimum przewóz lądowy na korzyść tańszego wodnego. 
Innym rezultatem badań geologiczno-archeologicznych jest uwypuklenie destrukcyjnego wpływu trzęsień ziemi na osadnictwo nie tylko współczesne, ale również w przeszłości.

\section{BIBLIOGRAFIA}

Asgari N.

1978 Roman and Early Byzantine Marble Quarries of Proconnesus, „Proceedings of the $\mathrm{X}^{\text {th }}$ International Congress of Classical Archaeology", Ankara, s. 467-480.

A ufhauser J.B.

1913 Miracula S. Georgii, Lipsiae.

Barsanti C.

1989 L'esportazione di marmi dal Proconneso nelle regioni pontiche durante il $\mathrm{IV}-\mathrm{VI}$ secolo, „Rivista dell Istituto Nazionale dell Archeologia e Storia dell Arte”, seric III, XII, Roma, s. $91-221$.

B e t s c h W.F.

1977 The History, Production and Distribution of the Late Antique Capital in Constantinople, „Univ. Pennsylvania Ph. Diss. Fine Arts” (Ann Arbor 1979).

Biernacki A.B., Pawlak P.

1997 Remarks on early christian architectural details made of Proconnesian marble and found in Novae (Moesia Inferior), Late Roman and early Byzantine Cities on the Lower Danube, „International Conference Poznań, Poland, 15-17 November 1995, Studies and Materials", Poznań.

B lü mner $\mathrm{H}$.

1884 Technologie und Terminologie der Gewerbe und Kunste bei Griechen und Römerm, Berlin.

Čaneva-Deč vska N.

1984 Church architecture of the First Bulgarian State, Sofia.

Czeżowski A.

1946 Kamieniotomy, Warszawa.

Deichmann F.W.

1969 Konstantinopler und Ravennatische Sarkophag-Probleme, ,.Byzantinische Zeitschrift”, 62, s. 291-307.

Durkin M.K., Lister C.J.

1983 The Rodos of Digenis. An Ancient Marble Quarry in Eastern Crete, „Annual of British School at Athens", 78, s. 69-96.

Encyklopedia

1997 Encyklopedia geograficzna świata, t. 6, Azja, Kraków.

Gore R.

2000 Gniew bogów. Trzęsienie ziemi w Turcji. Historia wykuwana przez katastrofy, „National Geographic", vol. 2 (7), s. 32-71.

H a s luk F.M.

1906 Notes on manuscripts in the British Museum relating to Levant geography and travel, „Annual of the British School at Athens", 12, London, s. 211-212.

1909 The Marmara Islands, ,Joumal of Hellenic Studies”, 29, London, s. 8-18.

1910 Cyzicus, Cambridge. 
Hermann J.C., Sodini J.P.

1977 Exportations de marbre thasien à l'époque paléochrétienne; le cas des chapiteaux ioniques, „Bulletin de Correspondance Hellénique”, 101, s. 471-511.

Herz N.

1988 Geology of Greace and Turkey: Potential marble source regions, „Classical Marble: Geochemistry, Technology, Trade", NATO ASI Series, s. 6-10.

Herzfeld E., Guyer S.

1930 Meriamlik und Korykos, Monumenta Asiae Minoris antiqua, Manchester.

Krautheimer R.

1980 Corpus Basilicarum Christianarum Romae, V, Citta del Vaticano.

Latyschev B.

1965 Inscriptiones Antiquae Orae Septentrionalis Pontis Euxinae, I.

Lemerle P.

1979 Les plus anciens Internatio recueils des miracles de Saint Dèmetrius, Paris.

Le psi us R.G.

1890 Griechische Marmorstudien, Berlin.

Lucas A.

1948 Ancient Egyptian Materials and Industries, London.

Megaw A.H.

1974 Byzantine architecture and decoration in Cyprus: Metropolitan or Provincial?, „Dumbarton Oaks Papers", 28, s. 57-88.

M i šar Z.

1987 Regionalni geologie sveta, Praha.

Mona D., Pensabene P.

1977 Marmi dell Asia Minore, Roma.

Piccardi L.

2000 Active faulting at Delphi, Greece: Seismotectonic remarks and a hypothesis for the geologic environment of a myth, „Geology”, vol. 28, No 7, s. 219-251.

Plinius Gaius Caesilius (Minor)

1982 Plinius der Jüngere.Briefe. Lateinisch und Deutsch von Helmut Kasten, Berlin.

Roder J.

1971 Marmor Phrygium. Die antiken Marmorbrïche von Iscehisar in Westanatolien, „Jahrbuch des Deutschen Archüologischen Instituts", 86, s. 254-312.

$\mathrm{Schläger} \mathrm{H.}$

1963 Abu Mena, ,.Kairo Mitteilungen”, 19, s. 114-120.

$\mathrm{Sch}$ neider A.M.

1951 Römische und byzantinische Bauten auf dem Garizim, „Zeitschrift des Deutschen PalastinaVereins", LXVIII, s. 211-234.

Sodin i J.P.

1977 Remarques sur la sculpture architecturale d'Attique, de Béothie et du Péloponnése à l'époque paléochrétienne, „Bulletin de Correspondance Hellénique”, 101, s. 423-450.

Tectonics

1982 Tectonics pf Europe and adjacent areas, Moscow.

Texier $C$.

1862 Asie Mineure, Paris.

Ward-Perkins J.B.

1972 Quarrying in Antiquity: Technology, Tradition and Social Change, „Mortimer Wheeler Archaeological Lecture", LVII, s. 138-158.

1980 Nicomedia and the Marble Trade, „Papers of the British School at Rome”, 48, s. 23-59. 
We is s $R$.

1964 Un umanista antiquario: Cristoforo Buondelmonti, „Letere Italiane”, 16, 2, s. 105-116.

White H.G.E.

1932 The Monasteries of the Wadin̆ Natrŭm, II, New York.

Wiegartz H.

1974 Marmorhandel, Sarkophagherstellung und die Lokalisierung der klein-asiatischen Saeulensarkophage, „Mélanges Mansel”, I, s. 315-350.

Wit ruwi usz

1999 O architekturze ksiag dziesięć, opr. Kazimierz Kumaniecki Warszawa.

$\mathrm{Zuchiewicz} \mathrm{W.}$

2000 Projekt IGCP 430. Wptyw dynamiki ptaszcza na zagrożenia naturalne $w$ obszarze tetydzkim, „Przegląd Geologiczny”, t . 48, nr 11, s. 971-990.

\section{THE ANCIENT PROCONNESOS QUARRIES. AN OUTLINE}

\section{S u m mary}

It has been generally known at least since the eighth century BC that marble quarries were at work on the Marmara island. However, they were only known on the basis of inscriptions and archaeological discoveries from beyond the island. It was only a construction of two breakwaters that made it possible to discover a large rubble layer covering an archaeological deposit.

This discovery led to an increase in interest not only in the quarries on the island but also in relationships with other sites in northern Turkey in which remains of stone workshops have been found.

Authors of this article visited the Marmara island in August 2000 during a short research stay. Its aim was recognition of current condition of the quarries and their ancient remains, preparation of photo and graphic documentation as well as collection of samples for petrographic, chemical, X-rays, and isotopic analyses. Results of chemical and physical analyses are believed to be useful for identification of the "Proconnesos" marbles in different archaeological deposits.

The Proconnesos marbles are not characterized by remarkable physical and aesthetic quality. A common and extensive distribution of sculptures and architectonic elements made of this marble was possibly caused by two elements: location of the island and richness of the deposit. The Marmara island was located on the sea route between the Mediterranean Sea, more particularly the Aegean Sea, and societies inhabiting territories north of the Black Sea. Thus, the island was of extreme political, strategic, and economic importance. Furthermore, the location of marbles near the coast made their transport easy and these conditions limited land transport to a minimum in favor of cheaper sea transport. 